\title{
PIBID: A RELEVÂNCIA DAS FEIRAS DE CIÊNCIAS PARA O INCENTIVO À PESQUISA.
}

Apresentação: Relato de Experiência

\author{
Joalis Barbalho de Souza ${ }^{1}$; Adriano Anastácio de Oliveira ${ }^{2}$; Jessica Nicolle \\ Rodrigues Matias ${ }^{3}$; Marcus Luiz dos Santos Menezes ${ }^{4}$
}

\section{Introdução}

As feiras de ciências são introduzidas nas escolas da rede pública de ensino na intenção de aprimorar os conhecimentos científicos dos discentes, proporcionando incentivos para a continuação de elaborações de projetos no decorrer de sua formação educativa. "A realização de projetos que envolvem pesquisas científicas pelos estudantes de ensino básico, para apresentação em feiras de ciências, tem se mostrado uma importante metodologia no desenvolvimento de novas competências nos estudantes" (Santos, 2012, p. 156).

Muitos alunos se sobressaem nas apresentações de suas amostras de trabalho, gerando ainda mais confiabilidade e posteriormente à construção de intercâmbios de ideias entre as escolas e até mesmo entre países. As feiras geram grandes expectativas tanto para os alunos e professores, quanto para os familiares dos alunos empenhados na construção dos seus trabalhos. Também destacamos à participação de grandes autoridades, reconhecidos socialmente pela população local, como diretores, coordenadores e autoridades políticas na feira de ciências, contribui para que o aluno se sinta reconhecido e assim proporcione maior rendimento na execução dos trabalhos.

No decorrer da feira de ciências, são apresentados uma variedade de projetos que envolve diversas áreas disciplinas, sempre relacionando com o cotidiano dos mesmos. Desse modo, "Os estudantes ainda desenvolvem o interesse pelos assuntos relacionados a diferentes áreas do conhecimento e habilidades para a busca de informações e aprendizagem contínua (...)" (Santos, 2012, p. 157). Os alunos se inspiram na possibilidade de melhoria de vida, e assim desenvolvem os seus trabalhos.

\section{Relato de Experiência}

A Escola Estadual Manoel de Melo Montenegro - EEMMM, situada no município de Ipanguaçu/RN, durante os últimos anos, vem realizando feiras de ciências,

\footnotetext{
${ }^{1}$ Licenciatura em Química, IFRN - Campus Ipanguaçu, joalisbarbalho11@hotmail.com

2 Licenciatura em Química, IFRN - Campus Ipanguaçu, adrianoanastacio90@gmail.com

${ }^{3}$ Professora da EEMMM, Escola Estadual Manoel de Melo Montenegro, Ipanguaçu, nicollemattias@gmail.com

${ }^{4}$ Professor do Curso de Licenciatura em Química, IFRN - Campus Ipanguaçu, marcus.menezes@ifrn.edu.br
} 
tendo como propósito selecionar os melhores projetos para a feira regional da $11^{\mathrm{a}}$ DIREC, realizada na cidade de Assú/RN. Desse modo, essa atividade vem incentivando os discentes à resolverem os problemas de sua cidade que os inquietam. O projeto é formado por três alunos matriculados na escola, um professor da rede estadual de ensino e um coorientador.

Os bolsistas atuantes do Programa Institucional de Bolsas de Iniciação à Docência - PIBID, da área de Química, que desenvolvem atividades de intervenções na referida escola campo, decidiram em uma das reuniões de planejamento, auxiliar os orientandos da professora supervisora em seus projetos. E, partindo disso, cada bolsista ficou responsável em coorientar um projeto entre 05 turmas da $1^{\mathrm{a}}$ até a $3^{\mathrm{a}}$ série do ensino médio.

Durante o mês que antecedia a feira, ocorreram várias visitas na escola campo para acompanhar o desenvolvimento dos alunos em seus projetos, e auxiliar no que for necessário. Os bolsistas auxiliarem os alunos na escolha da questão problema, das formulações das hipóteses, construção do diário de bordo, elaboração do banner, e até na sua postura de apresentação. A professora supervisora disponibilizou os horários da disciplina de Química para que os bolsistas se reunissem os seus grupos.

A feira de ciência foi realizada no dia 04 de agosto de 2017 no turno matutino e noturno na escola citada. Dentro dos três projetos que os avaliadores da $11^{\mathrm{a}}$ DIREC selecionaram para participar da feira de ciências regional, dois projetos foram com a coorientação dos bolsistas do PIBID. Também teve três projetos selecionados para participar da Mostra Científica do Instituto Federal de Educação, Ciência e Tecnologia do Rio Grande do Norte - campus Ipanguaçu, no dia 29 de agosto de 2017, na modalidade de exposição de banner.

\section{Considerações}

A ação do PIBID/INTERDISCIPLINAR, área de Química foi de grande relevância para que os discentes pudessem despertar o método científico, incentivando à pesquisa, possibilitando que os mesmos busquem respostas para as suas indagações. Para os bolsistas, esta atividade proporcionou a experiência de participar de uma feira de ciências antes de sua formação como docente, reafirmando o objetivo do programa em questão, ou seja, antecipando as experiências da prática docente.

\section{Referências}

SANTOS, A. B. Feiras de Ciência: Um incentivo para desenvolvimento da cultura científica. Rev. Ciênc. Ext. v.8, n.2, p.155-166, 2012. 